\title{
Calcium as a Plant Nutrient
}

\author{
Rajendra Prasad and Yashbir Singh Shivay*
}

Division of Agronomy, ICAR-Indian Agricultural Research Institute, New Delhi (110 012), India

fi Corresponding Author

Yashbir Singh Shivay

e-mail: ysshivay@hotmail.com

Citation: Prasad and Shivay, 2020. Calcium as a Plant Nutrient. International Journal of Bio-resource and Stress Management 2020, 11(5), i-iii. HTTPS://DOI. ORG/10.23910/1.2020.2075a

Copyright: (c) 2020 Prasad and Shivay. This is an open access article that permits unrestricted use, distribution and reproduction in any medium after the author(s) and source are credited.

Data Availability Statement: Legal restrictions are imposed on the public sharing of raw data. However, authors have full right to transfer or share the data in raw form upon request subject to either meeting the conditions of the original consents and the original research study. Further, access of data needs to meet whether the user complies with the ethical and legal obligations as data controllers to allow for secondary use of the data outside of the original study.

Conflict of interests: The authors have declared that no conflict of interest exists.
Article History

RECEIVED in $20^{\text {th }}$ February 2020 RECEIVED in revised form $02^{\text {nd }}$ October 2020 ACCEPTED in final form $14^{\text {th }} 0$ 0ctober 2020

\begin{abstract}
Calcium (Ca) is an essential plant nutrient responsible for the integrity of cells and plant structure, yet it is generally neglected, because it is available in plenty in most cultivated soils. It is therefore not applied as a fertilizer to crops except in groundnut. In acid soils, where it is limiting, it is applied in large amounts as a soil amendment as lime. In sodic soil, where excess of Na creates problems in crop production $\mathrm{Ca}$ is applied as gypsum, another soil amendment. When applied in large amounts as lime or gypsum, Ca nutrition is already taken care of and thus there is no need of annual application as a fertilizer. Nevertheless its importance as a plant nutrient cannot be ignored.
\end{abstract}

Keywords: Acid soils, gypsum, groundnut, lime, plastering, soil amendments

\section{Introduction}

Among the essential plant nutrients Calcium (Ca) is third in abundance after $\mathrm{N}$ and $\mathrm{K}$ and is very close to $\mathrm{P}$ in abundance in plant tissue. The highest amounts of $\mathrm{Ca}$ are found in mitochondria. It is involved in cell division and cell elongation (Helper, 1994). It is a messenger in several developmental and environmental changes (Heintz, 1960; Sanders et al., 2002). It is responsible for cell integrity (Zhang et al., 2018) and therefore in plant survival. Calcium is akin to boron in pollen tube germination and elongation (Wang et al., 2003; White and Broadley, 2003; Prasad et al., 2014; Zheng et al., 2019). Calcium in cells is present as $\mathrm{Ca}^{2+}$ ions or as insoluble compounds in association with organic molecules in apoplast. In cell walls it is associated with pectin linkages and is therefore in plant structure. In some plants calcium is present as insoluble crystalline calcium oxalate as a protection mechanism (Prasad and Shivay, 2017). As Ca is relatively less mobile in plants its deficiency is most noticeable on younger leaves or growing points and fruits, which may display dead spots, crinkling, spotting / mottling, small brown spots and stunted growth. Some, well - known Ca deficiency diseases are brown pit in apple, cavity pit in carrots and blossom end rot of bell pepper (Prasad et al., 2016).

\section{Physiological Role of Calcium}

Calcium is well known for its role in cell division and cell elongation. A large part of the calcium in most plants is located in the leaves and more calcium is present in the older than in the younger leaves. In many plant 
species calcium is present in the form of insoluble crystals of calcium oxalate. Calcium also forms salts with other organic acids and enter into chemical combination with protein molecules. It is important for nitrate reduction in plant tissues (Jena and Rout, 2016).

\section{Enzyme Activity}

An important function of $\mathrm{Ca}^{2+}$ is the activation of a number of enzymes including cyclic nucleotide phosphor-diesterase, adenylate cyclase. Membrane bound $\mathrm{Ca}^{2+}$ ATPase and NADKinase which it performs in association with calomdulin. Calmodulin is a polypeptide of 148 amino acids stable and sensitive to $\mathrm{pH}$ (Jena and Rout, 2016).

Despite being responsible for so many functions, calcium is never applied as a fertilizer, because it is available in plenty in neutral $(p \mathrm{H} \mathrm{7.0)}$ or near neutral soils. However it is present in fairly large amounts in phosphate fertilizers (single and triple phosphate) and in nitrogen fertilizer like calcium ammonium nitrate (Nitro-chalk in Europe). In acid soils (below pH 6.8) and in sodic soils (above $p \mathrm{H} \mathrm{8.0)}$ ) it is applied as a soil amendment in large amounts and Ca nutrition is taken care of. However, $\mathrm{Ca}$ is used as a fertilizer in groundnut.

\section{Response of Calcium Application in Groundnut}

In groundnut, after fertilization, gynophore penetrates the soil and pod develops underground. The calcium requirements are high and the plant roots are not able to absorb and supply enough $\mathrm{Ca}$ for the pod development. In a study using labeled Ca, when it was applied as to the fruit zone, $88.3 \%$ was absorbed by the fruits and the rest went to other parts of plant, however, when it was supplied in the root zone about $66 \%$ was absorbed by the roots themselves (Chahal and Virmani, 1973). Ramachandran and Kulkarni (1992) showed that, while a Ca-saturation of $25 \%$ in exchange complex was adequate in sandy soils, heavy clay soils needed a Ca saturation of $75 \%$

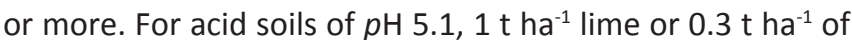
gypsum is recommended for groundnut (Raddar and Biradar, 1973). In USA, Carolina's peanut industry, especially the large percentage of Virginia-type peanuts grown, has created a big need for calcium fertilization, commonly referred to as 'landplastering' (Roberson, 2009).

\section{Calcium in Soils}

Calcium is the fifth abundant element in earth's crust after $\mathrm{O}, \mathrm{Si}, \mathrm{Al}$ and $\mathrm{Fe}$ ) and makes up about 3.64\% (by weight) of earth's crust (Mengel and Kirkby, 1987). It is present in earth as mineral deposits of calcite $\left(\mathrm{CaCO}_{3}\right)$, dolomite $\left(\mathrm{CaCO}_{3}\right.$ $\left.\mathrm{MgCO}_{3}\right)$, gypsum $\left(\mathrm{CaSO}_{4} \cdot 2 \mathrm{H}_{2} \mathrm{O}\right)$ and appetites or phosphorites $\left\{3\left[\mathrm{Ca}_{3}\left(\mathrm{PO}_{4}\right)_{2}\right] \mathrm{CaX}\right\}$, where ' $\mathrm{X}$ ' could be $\mathrm{F}, \mathrm{Cl}, \mathrm{OH}$ or $\mathrm{CO}_{3}$. Calcium is also a component of silicate minerals viz. anorthite, augite, hornblende and albite (Prasad, 2007). Calcium content in soils depends upon the parent material and weathering. In leached humid tropics it may range from 0.1 to $0.3 \%$, while in calcareous soils it may range from $<1 \%$ to $25 \%$. In general, a Ca content of $3 \%$ indicates the presence of free calcium carbonate (Jena and Rout, 2016). In soils Ca occurs in three forms, namely, insoluble minerals, exchangeable $\mathrm{Ca}$ and $\mathrm{Ca}$ in solution. Generally there tends to be an equilibrium between three forms. A large amount of calcium is present as exchangeable $\mathrm{Ca}$ on silicate minerals in soils having $p \mathrm{H} 6.0$ or above, it can range from $<25$ to $5000 \mathrm{mg} \mathrm{kg}^{-1}$ soil. Calcium in soil solution can range from 6 to $778 \mathrm{mg} \mathrm{kg}^{-1}$ soil (Prasad and Power, 1997).

\section{Interaction of Calcium with Other Plant Nutrients}

Calcium being the base cation in exchange complex of the soil generally positively interacts with most plant nutrients. Among the primary nutrients, $\mathrm{Ca}$ interacts positively with $\mathrm{N}$ in crop production. However, application of acid forming nitrogen fertilizers, such as, ammonium sulphate, ammonium chloride, ammonium nitrate, anhydrous ammonia and urea deplete soil calcium. To replace $\mathrm{Ca}$ depleted due to acid forming nitrogen fertilizers 84 to $148 \mathrm{~kg}$ lime $\left(\mathrm{CaCO}_{3}\right)$ is required per $100 \mathrm{~kg}$ fertilizer (Prasad and Power, 1997). Calcium and phosphorus are supportive of each other and the first phosphate fertilizer made was single superphosphate containing $\mathrm{CaH}_{2} \mathrm{PO}_{4}$ and $\mathrm{CaSO}_{4}$. However in neutral and above neutral soil, when heavy phosphorus applications are made, Ca may be precipitated, but even tri-calcium phosphate is available to crop plants. As regards K, both $\mathrm{Ca}$ and $\mathrm{K}$ compete for absorption sites and at normal rates of $\mathrm{K}$ application only a positive interaction is reported between the two nutrients.

Among the secondary nutrients $\mathrm{Ca}$ and $\mathrm{S}$ are supportive to each other and that is why gypsum is a preferred fertilizer for groundnut as compared to lime $\left(\mathrm{CaCO}_{3}\right)$. $\mathrm{Mg}$ and $\mathrm{Ca}$ may compete each other for adsorption site on roots and only at very high rates of $\mathrm{Mg}$ application it may interfere with $\mathrm{Ca}$ nutrition. Dolomite is used as a liming material.

In acid soils, liming helps in removing $\mathrm{Fe}$ and $\mathrm{Mn}$ toxicity. These two plant nutrients and Al can reach toxicity limits in acid soils. Mukherjee et al. (1947) pointed out the importance of exchangeable Al in soil acidity and Foy (1992) pointed out that in acid soils exchangeable Al did most damage to plants. Heavy liming may however lead to Fe deficiency.

Since both $\mathrm{Ca}$ and $\mathrm{B}$ are less mobile in plants, they generally support each other in fruit development. Very high Ca uptake may cause B deficiency. A Ca: B ratio of 100-400 is considered for good crop yields (Jena and Rout, 2016).

\section{Conclusion}

Calcium is an essential plant nutrient but is not needed to be applied every season/year, because it is available in plenty in neutral soils, while in acid soils it is applied in large amounts as lime and in sodic soils it is applied as gypsum. Also it is an important component of some phosphorus and nitrogen fertilizers. However, its application as gypsum or lime (in acid soils) in groundnut at pegging stage is essential for good pod 
development.

\section{References}

Chahal, R.S., Virmani, M.S., 1973. Uptake and translocation of nutrients in groundnut. 1. Ca. Oleaagineaux 80, 181-184.

Foy, C.D., 1992. Soil chemical factors limiting plant growth. Advances in Soil Sciences 19, 97-149.

Heintz, S.G., 1960. Studies on cation-exchange capacities of roots. Plant and Soil 13, 365-383.

Helper, P.K., 1994. Effect of calcium in cell division. Cell Calcium 16(4), 322-330.

Jena, D., Rout, K.K., 2016. Calcium and magnesium management. In: Prasad, R., Kumar, D., Rana, D.S., Shivay, Y.S., Tewatia, R.K. (Eds.), Textbook of Plant Nutrient Management, Indian Society of Agronomy, New Delhi, 157-181.

Mengel, K., Kirkby, B.A., 1987. Principles of plant nutrition. Panima Educational Book Agency, New Delhi.

Mukherjee, J.N., Chatterjee, B., Banerjee, B.M., 1947. Extraction of exchangeable $\mathrm{H}^{+}, \mathrm{Al}^{3+}$ and $\mathrm{Fe}^{3+}$ ions from hydrogen clays by neutral salts. Journal of Colloid Science 1, 247-254.

Prasad, R., Majumdar, K., Shivay, Y.S., Kapil, U., 2016. Minerals in plant and human nutrition, International plant nutrition institute, peachtree corners, GA, USA. 80.

Prasad, R., 2007. Crop nutrition, New Vishal Publication, New Delhi.

Prasad, R., Kumar, D., Shivay, Y.S., Rana, D.S., 2014. Boron in Indian agriculture - A review. Indian Journal of Agronomy 59(4), 511-517.

Prasad, R., Power, J.F., 1997. Soil fertility management for sustainable agriculture. CRC-Lewis Publishers, Boca Raton, FL, USA.

Prasad, R., Shivay, Y.S., 2017. Oxalic acid/oxalates in plants: from self-defence to phytoremediation. Current Science 112(8), 1665-1667.

Raddar, G.D., Biradar, B.M., 1973. Effect of gypsum application and topping of main shoot top on pod development and yield of groundnut. Oilseed Journal 3(4), 11-13.

Ramachandran, B.K., Kulkarni, K.K., 1992. Response of groundnut to Ca-saturation levels. Journal of Oilseeds Research 9, 51-58.

Roberson, R., 2009. Calcium requirements heavy in peanuts. Farm Progress, March 20, 2009.

Sanders, J., Pelloux, J., Brownlee, C., Harper, J.F., 2002. Calcium dependent sucrose uptake links sugar signaling to anthocyanin biosynthesis. Plant Cell 14, S401-S417.

Wang, L.Q., Longdou, L., Wu, X., Lin, J., 2003. Boron influences pollen germination and pollen tube growth in Piceameyer. Tree Physiology 23(5), 345-351.

White, P.J., Broadley, M.R., 2003. Calcium in plants. Annals of Botany 92(4), 487-511.

Zhang, H.U., Xu, Q., Xiong, Y., Peng, S.L., Kumari, K.M., Wei, D.Q., 2018. Membrane defect and water leakage caused by passive calcium permeation. Journal of Molecular Liquids 270, 227-233. https://doi.org/10.1016/j. molliq.2017.12.127.

Zheng, R.H., Su, S.D., Xiao, H., Tian, H.Q., 2019. Calcium: A critical factor in pollen germination and tube elongation. International Journal of Molecular Science 20(2), 420. 